\title{
Article \\ Effects of Organic Energy Crop Rotations and Fertilisation with the Liquid Digestate Phase on Organic Carbon in the Topsoil
}

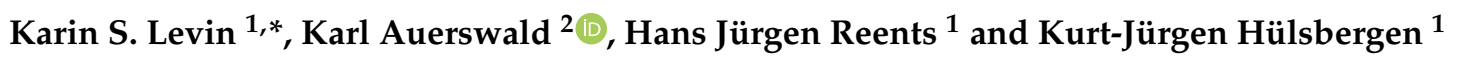 \\ 1 Chair of Organic Agriculture and Agronomy, Technical University of Munich, Liesel-Beckmann-Str. 2, \\ 85354 Freising, Germany; reents@wzw.tum.de (H.J.R.); huelsbergen@wzw.tum.de (K.-J.H.) \\ 2 Aquatic Systems Biology Unit, Technical University of Munich, Alte Akademie 12, 85354 Freising, Germany; \\ auerswald@wzw.tum.de \\ * Correspondence: karin.levin@tum.de
}

check for

updates

Citation: Levin, K.S.; Auerswald, K.; Reents, H.J.; Hülsbergen, K.-J. Effects of Organic Energy Crop Rotations and Fertilisation with the Liquid Digestate Phase on Organic Carbon in the Topsoil. Agronomy 2021, 11, 1393. https://doi.org/10.3390/ agronomy 11071393

Academic Editors: Alwyn Williams and Hailin Zhang

Received: 22 May 2021

Accepted: 4 July 2021

Published: 10 July 2021

Publisher's Note: MDPI stays neutral with regard to jurisdictional claims in published maps and institutional affiliations.

Copyright: (c) 2021 by the authors. Licensee MDPI, Basel, Switzerland. This article is an open access article distributed under the terms and conditions of the Creative Commons Attribution (CC BY) license (https:// creativecommons.org/licenses/by/ $4.0 /)$.

\begin{abstract}
Combining organic farming and biogas production from agricultural feedstocks has been suggested as a way of achieving carbon (C) neutrality in Europe. However, as the long-term effects of $\mathrm{C}$ removal for methane production on soil organic carbon (SOC) are unclear, organic farmers in particular have questioned whether farm biogas production will have a positive effect on soil fertility. Eight years of data from an organic long-term field trial involving digestate fertilisation and various crop rotations (CRs) with differing proportions of clover-grass leys were used to calculate C inputs based on the CANDY model, and these modelled changes compared with measured changes in SOC content (SOCC) over the same period. Measured SOCc increased by nearly $20 \%$ over the eight years. Digestate fertilisation significantly increased SOCc. Fertilised plots with the highest proportion of clover-grass in the CR had the highest SOCc. The $\mathrm{C}$ inputs from clover-grass leys, even if they only made up $25 \%$ of the CR, were high enough to increase SOCc, even with the removal of all aboveground biomass and without fertilisation. Our results show that biogas production based on clover-grass leys could be an important part of sustainable farming, improving or maintaining SOCc and improving nutrient flows, particularly in organic farming, while simultaneously providing renewable energy.
\end{abstract}

Keywords: biogas; ley; organic agriculture; carbon input; clover-grass; digestate

\section{Introduction}

Organic farmers in particular are reliant on organic inputs as nutrient sources, as the use of synthetic chemical fertilisers is not permitted in organic farming (see, e.g., The Council of the European Union [1]). Organic fertilisers, however, are usually available in lower amounts than synthetic fertilisers. The nutrients in organic fertilisers often have to be mineralised in soils first before they can be used by crops [2]. As a result, organic farmers are therefore also reliant on soil organic matter acting as a reservoir for nutrients necessary for crop growth [3]. It is, hence, particularly important in organic agriculture that soil organic matter contents are, at the very least, maintained. Preservation of soil organic matter also has other benefits such as improved soil structure and therefore increased water infiltration and storage, and lower erosion risk. Improving soil quality is hence an important part of climate change adaptation in agriculture. Carbon (C) sequestration consequently contributes to food security by improving soil quality [4].

$\mathrm{C}$ sequestration in soils is itself essential for climate change mitigation, as is the transition to renewable energies. A scenario for achieving $C$ neutrality in Europe developed by Aubert et al. [5] recommends reducing livestock numbers and instead using grassland biomass for biogas production. As the proportion of farms without livestock is increasing in organic farming in Germany [6], a similar approach could also appeal to organic farmers. Harvesting the biomass from forages such as clover-grass leys for biogas production instead of mulching provides an additional source of income and has been shown to be 
more profitable, despite the large investment required [7]. There are also other advantages, such as lower nitrous oxide emissions [8] and improved nitrogen $(\mathrm{N})$ fixation [9].

Digestates resulting from the anaerobic digestion of organic material for the production of biogas can have higher ammonium $\left(\mathrm{NH}_{4}{ }^{+}\right): \mathrm{N}$ ratios than the original feedstocks, and crop $\mathrm{NH}_{4}{ }^{+}-\mathrm{N}$ recoveries equivalent to mineral fertilisers [10]. This relatively high content of plant-available $\mathrm{N}$ means digestates are valuable organic fertilisers, particularly for organic farmers. The timing of $\mathrm{N}$ availability from mineralisation of soil organic matter and crop residues is difficult to control, and this is one reason for lower yields in organic agriculture [11]; being able to provide $\mathrm{N}$ to crops when they require it could improve yields. Higher productivity also contributes to more $\mathrm{C}$ sequestration in soils, as more crop residues and root biomass can be incorporated into soils [12]. However, improved $\mathrm{N}$ supply and availability may lower $\mathrm{C} / \mathrm{N}$ ratios in crop litter and residues, increasing decomposition rates $[13,14]$. Nonetheless, this $\mathrm{C}$ may still be incorporated into stable soil organic matter fractions [15].

During anaerobic digestion, labile, easily decomposable organic compounds are broken down and transformed into methane and carbon dioxide. $\mathrm{C}$ content is therefore generally lower in digestates than in the substrates, such as animal manures, used in their production [16]. Lower $\mathrm{C}$ content and higher content of available $\mathrm{N}$ could lead to the priming effect increasing $C$ losses from soils $[17,18]$; this could particularly be the case in organically-managed soils, which usually have lower levels of available N [11]. Digestate application could also change soil microbial community composition, as labile $\mathrm{C}$ fractions have already been decomposed during the digestion process. There could therefore be a reduction in soils of microbes specialised in the decomposition of these compounds [19]. In addition, digestates themselves consist of microbial biomass [20], but most likely with a different composition than that of the original substrate [21,22]. The proportion of $C$ remaining in digestates that is more resistant to decomposition is higher than in the original substrates [23]. However, the compounds contained in this "stable" fraction, such as lignin, will vary according to the substrates used [24], and thus digestate stability in soil will also vary [17]. Organic farmers in particular have therefore questioned whether anaerobic digestion of organic amendments, such as manures, composts and crop residues, and then fertilising with digestate has a positive effect on soil organic matter and fertility [25] in comparison to simply using the substrates themselves, particularly as the long-term effects on soil C content of digestate fertilisation in the field are unclear [26].

Legumes are one of the main sources of $\mathrm{N}$ in organic farming systems and green manures such as clover-grass leys are often used in organic arable farming to provide $\mathrm{N}$ to subsequent crops $[11,27]$. Another advantage is that clover-grass leys increase $C$ content in the topsoil compared with arable crops [28,29], due, for example, to higher $\mathrm{C}$ input to soils from clover-grass leys than for other arable crops such as maize [30]. Börjesson et al. [31] calculated negative greenhouse gas emissions (i.e., $\mathrm{C}$ removal from the atmosphere) for a biogas system based on clover-grass leys due to significant soil organic $\mathrm{C}$ accumulation. However, many life cycle assessments or $\mathrm{C}$ footprint analyses of energy production from biomass do not include changes in soil $\mathrm{C}$ as the methodology is unclear [32]. In addition, while there are models available that can be used to calculate changes in soil $\mathrm{C}$ due to the addition of organic fertilisers, these do not currently include digestates [33].

The aim of this paper is to investigate the effects of digestate fertilisation and crop rotations for biogas production based on clover-grass leys on soil organic carbon content $(\mathrm{SOC})$. Eight years of data from an organic long-term field trial involving digestate fertilisation and various crop rotations (CRs) with differing proportions of clover-grass leys were used to calculate C inputs based on the CANDY model [34], and these modelled changes compared with measured changes in SOCc over the same period. Most studies to date investigating the effects of digestate fertilisation on SOC have been short-term lab experiments rather than field experiments [25]. It can, however, take many years before changes in soil C become apparent [35], and complex feedback mechanisms may be at work that substantially modify short-term responses in the long run. In addition, many of these 
studies use digestates based on liquid animal manures and/or maize silage, whereas the digestate used in our field trial is produced by an organic farm and is based on clover-grass and grass silage, and therefore more accurately represents the types of digestates that could be used in future sustainable farming scenarios [5].

\section{Materials and Methods}

\subsection{Experimental Site}

Our field trial (Figure 1) was situated at the Technical University of Munich's (TUM) agricultural research station in Viehhausen. Viehhausen is located approximately $8 \mathrm{~km}$ west of Freising in southern Germany, $490 \mathrm{~m}$ above sea level in the Tertiary hill country, an undulating landscape developed in unconsolidated Tertiary sediments and overlain by a thin loess cover. Using the US soil taxonomy [36], the soil at the experimental site is categorised as a Hapludalf derived from loess with silty loam texture down to at least $1 \mathrm{~m}$. Using the World Reference Base [37], the soil is a Haplic Luvisol (Manganiferric, Siltic). Average clay content was $25 \%$. The experiment was situated on a slope facing north-east with a gradient of about $9 \%$. Average annual temperature and precipitation for the period 2010-2017 in Viehhausen were $9.0^{\circ} \mathrm{C}$ and $799 \mathrm{~mm} \mathrm{a}^{-1}$, respectively. The field trial began in late 2004 and has been running in its present form since 2007.

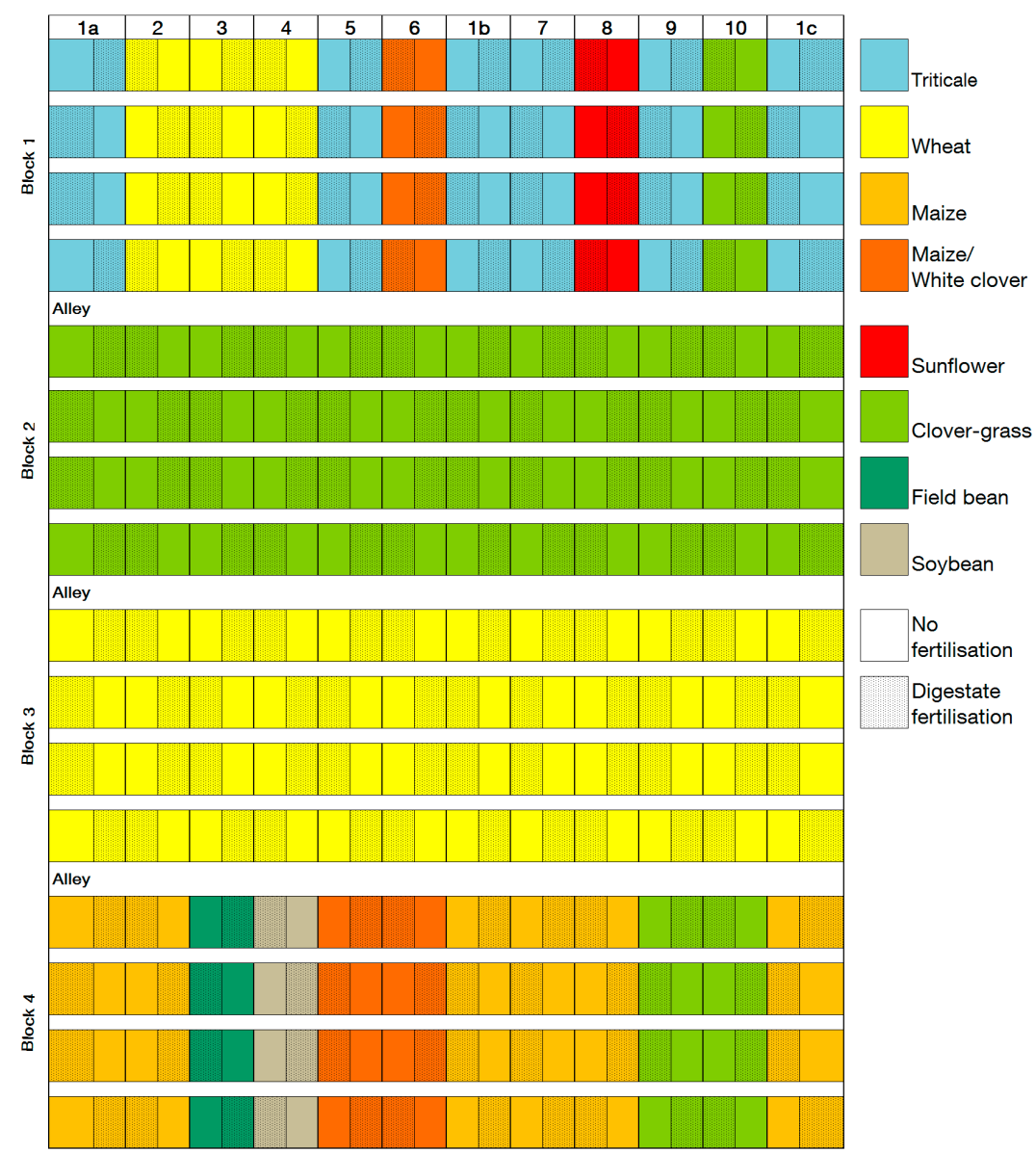

Figure 1. Field trial plot plan 2017. For dimensions see text. Crop rotations are indicated in the top row.

\subsection{Digestate and Fertilisation}

The main factor studied in the field trial was fertilisation using biogas digestate, which was assigned in two levels to plots within the factor CR; there were ten different CRs and the 32 plots of each CR were divided into 16 fertilised and 16 unfertilised plots (Figure 1). 
Each unfertilised plot was neighboured laterally by a fertilised plot on one side across the slope and on one side along the slope. There was no difference in treatment between fertilised and unfertilised plots except that fertilised plots were fertilised using biogas digestate. Each CR received a different amount of digestate, depending on the theoretical amount of digestate that could be produced from the estimated crop biomass of clovergrass, rye (wholecrop) (Secale cereale L.), silage maize (Zea mays L.), triticale (wholecrop) (x Triticosecale Wittmack) and sunflower (wholecrop) (Helianthus annuus L.) grown in the fertilised plots of each CR. The total amount of digestate was then divided among the crops in the CR according to estimated nutrient requirements. The amount of $C$ added via digestate to each plot therefore ranged from 0 to $3 \mathrm{t} \mathrm{ha}^{-1} \mathrm{a}^{-1}$. The digestate was applied using a slurry tanker fitted with trailing hoses. The digestate was produced by a local organic farmer from a feedstock mix of, on average, 61\% silage from clover-grass ley/grass ley/grassland biomass, 30\% solid cattle manure, 5\% silage maize and the remainder cereal grains. From 2010 onwards, the digestate was separated into liquid and solid phases and the liquid phase used in this field trial (for the sake of simplicity, we refer only to digestate). The average dry matter content of the digestate after separation of the solids was $7.9 \%$, with a total C content of 39\% (Table 1). Digestate $\mathrm{pH}$ was 7.8 (data from 2015 only). Digestate samples were analysed according to the following German standards: DIN 38414-S2 or DIN EN 12880 (S 2a) for dry matter content, DIN 38414-3 (S 3) for loss on ignition, DIN ISO 13878 for total N, DIN 38406-5 (E 5) for ammonium N, DIN EN ISO 11885 for phosphate, potassium and sulphur, and total $\mathrm{C}$ according to Dumas.

Table 1. Average composition of the digestate applied in the field trial (liquid phase) 2010-2017 ( $n=13$, standard deviation in parentheses, laboratory analysis by Agrolab Labor $\mathrm{GmbH}$ ).

\begin{tabular}{cc}
\hline Variable & $\begin{array}{c}\text { Content } \\
\text { Dry Weight Basis) }\end{array}$ \\
\hline Loss on ignition & $71.4(1.9)$ \\
Total carbon & $39.2(0.9)$ \\
Total nitrogen & $6.1(0.9)$ \\
Ammonium nitrogen & $3.4(0.7)$ \\
Phosphate (as $\left.\mathrm{P}_{2} \mathrm{O}_{5}\right)$ & $2.2(0.2)$ \\
Potassium $\left(\right.$ as $\left._{2} \mathrm{O}\right)$ & $8.9(0.9)$ \\
Sulphur & $0.47(0.04)$ \\
\hline
\end{tabular}

\subsection{Experimental Design}

The factor CR comprised 10 different four-year crop rotations (Table 2). The CRs were laid out in a replicated control design. CR1a was located at the start of the field, repeated in the middle (CR1b) and at the opposite end of the field (CR1c) in order to capture any trends in yield potential across the site. Each crop of every CR was cultivated each year; the CRs were therefore laid out in columns running down the field, divided into four blocks. The crops moved up a block each year. Within each CR there were 8 replications in each block ( 4 fertilised and 4 unfertilised plots). Plots measured $6 \mathrm{~m} \times 12 \mathrm{~m}$ (plots on both outer edges of the trial measured $9 \mathrm{~m} \times 12 \mathrm{~m}$ ), with alleys of $3 \mathrm{~m}$ between each row of plots and $9 \mathrm{~m}$ between each block. The field trial therefore had a total size of nearly 4 ha.

The first year in each CR was a lucerne-clover-grass ley or clover-grass ley. The clovergrass leys were mixtures of red clover (both diploid and tetraploid, Trifolium pratense L.) and white clover (Trifolium repens L.) with various grasses, such as orchard grass (Dactylis glomerata L.), meadow fescue (Festuca pratensis Huds.) or Italian ryegrass (Lolium multiflorum Lam.). The lucerne-clover-grass leys also included lucerne (Medicago sativa L.). For the sake of simplicity, we refer only to clover-grass. The ley year was followed by a year of winter wheat (Triticum aestioum L.); the CRs differed in the third and fourth years. All aboveground biomass was harvested and removed (including wheat straw), with the following exceptions: field bean (Vicia faba L.) and soybean (Glycine max (L.) Merr.) straw in CRs 3 and 4; year 3 cover crops in CRs 3, 4, 7 and 8 (mulched); white clover in CRs 5 and 
6 (mulched). Leys were cut 3-5 times per year. Conventional tillage (ploughing to a depth of approximately $22 \mathrm{~cm}$ ) was used. As ploughing depended on which crop was grown, plots were not ploughed every year.

Table 2. Plan of crop rotations and mean amount of digestate fertilised in the fertilised plots, 2010-2017 (numbers in parentheses indicate digestate amount in the fertilised plots, $\mathrm{m}^{3} \mathrm{ha}^{-1} \mathrm{a}^{-1}$ ).

\begin{tabular}{|c|c|c|c|c|c|}
\hline $\begin{array}{c}\text { Crop } \\
\text { Rotation }\end{array}$ & Year 1 & Year 2 & $\begin{array}{c}\text { Year } 3 \text { Cover } \\
\text { Crop }\end{array}$ & Year 3 & Year 4 \\
\hline CR1a & $\begin{array}{c}\text { Lucerne- } \\
\text { clover-grass }\end{array}$ & Wheat (40) & Rye (16) & Maize (55) & Triticale (38) \\
\hline CR2 & $\begin{array}{c}\text { Lucerne- } \\
\text { clover-grass }\end{array}$ & Wheat (30) & Rye (16) & Maize (53) & Wheat (31) \\
\hline CR3 & $\begin{array}{c}\text { Lucerne- } \\
\text { clover-grass }\end{array}$ & Wheat (28) & $\begin{array}{l}\text { Legume/ } \\
\text { non-legume } \\
\text { mixture }\end{array}$ & Field bean & Wheat (29) \\
\hline CR4 & $\begin{array}{c}\text { Lucerne- } \\
\text { clover-grass }\end{array}$ & Wheat (31) & $\begin{array}{l}\text { Legume/ } \\
\text { non-legume } \\
\text { mixture }\end{array}$ & Soybean & Wheat (29) \\
\hline CR5 & $\begin{array}{c}\text { Lucerne- } \\
\text { clover-grass }\end{array}$ & Wheat (45) & $\begin{array}{l}\text { White clover } \\
\text { (3) }\end{array}$ & $\begin{array}{c}\text { Maize and } \\
\text { white clover } \\
(45)\end{array}$ & Triticale (40) \\
\hline CR6 & Clover-grass & Wheat (43) & $\begin{array}{l}\text { White clover } \\
\text { (3) }\end{array}$ & $\begin{array}{c}\text { Maize and } \\
\text { white clover } \\
(42)\end{array}$ & $\begin{array}{l}\text { Maize and white } \\
\text { clover }(44)\end{array}$ \\
\hline CR1b & $\begin{array}{c}\text { Lucerne- } \\
\text { clover-grass }\end{array}$ & Wheat (40) & Rye (16) & Maize (55) & Triticale (38) \\
\hline CR7 & $\begin{array}{c}\text { Lucerne- } \\
\text { clover-grass }\end{array}$ & Wheat (38) & $\begin{array}{l}\text { Legume/ } \\
\text { non-legume } \\
\text { mixture (8) }\end{array}$ & Maize (38) & Triticale (40) \\
\hline CR8 & $\begin{array}{c}\text { Lucerne- } \\
\text { clover-grass }\end{array}$ & Wheat (45) & $\begin{array}{l}\text { Legume/ } \\
\text { non-legume } \\
\text { mixture (8) }\end{array}$ & Maize (36) & $\begin{array}{l}\text { Sunflower and } \\
\text { undersown } \\
\text { lucerne- } \\
\text { clover-grass (34) }\end{array}$ \\
\hline CR9 & $\begin{array}{c}\text { Lucerne- } \\
\text { clover-grass } \\
(40)\end{array}$ & Wheat (69) & $\begin{array}{c}\text { Lucerne- } \\
\text { clover-grass }\end{array}$ & $\begin{array}{c}\text { Lucerne- } \\
\text { clover-grass }\end{array}$ & Triticale (45) \\
\hline CR10 & $\begin{array}{c}\text { Lucerne- } \\
\text { clover-grass } \\
(50)\end{array}$ & Wheat (77) & $\begin{array}{c}\text { Lucerne- } \\
\text { clover-grass }\end{array}$ & $\begin{array}{c}\text { Lucerne- } \\
\text { clover-grass }\end{array}$ & $\begin{array}{c}\text { Lucerne- } \\
\text { clover-grass (20) }\end{array}$ \\
\hline CR1c & $\begin{array}{c}\text { Lucerne- } \\
\text { clover-grass }\end{array}$ & Wheat (40) & Rye (16) & Maize (55) & Triticale (38) \\
\hline
\end{tabular}

\subsection{Sampling}

Soil samples (6-8 per plot) were taken in October 2009 and again in October 2017 in all plots $(n=384)$ to a depth of $30 \mathrm{~cm}$, using a Pürckhauer auger. The soil samples were sieved to $2 \mathrm{~mm}$ and air-dried. The results of analyses of the 2009 soil samples were assumed to be the starting values for the soil in 2010.

Biomass and grain yields (Table 3 ) were determined each year using a plot harvester and plot combine, respectively. Straw and cover crop biomass yields were also measured, but not in all years. The $\mathrm{C}$ content of soil and crop grain and biomass samples was analysed using a $\mathrm{C}$ and $\mathrm{N}$ analyser (Vario Max, Elementar Analysensysteme $\mathrm{GmbH}$, Dumas combustion method). The mean crop $C$ content was between 43 and $45 \%$, with the exception of soybean, where the mean C content was 52\%. For the 2017 soil samples, if the 
$\mathrm{pH}$ indicated the presence of carbonates $(\mathrm{pH}>6.8)$, carbonate- $\mathrm{C}$ content was additionally determined after treatment in a muffle furnace at $550{ }^{\circ} \mathrm{C}$ [38]. The $\mathrm{pH}$ of the soil samples was measured in a $0.01 \mathrm{M} \mathrm{CaCl}_{2}$ solution using a $\mathrm{pH}$ meter.

Table 3. Mean crop yields 2010-2017 (DM = dry matter).

\begin{tabular}{|c|c|c|c|c|}
\hline \multirow[t]{3}{*}{ Crop } & \multicolumn{4}{|c|}{ Mean Yield } \\
\hline & \multicolumn{2}{|c|}{ Biomass (DM, $\mathrm{tha}^{-1} \mathrm{a}^{-1}$ ) } & \multicolumn{2}{|c|}{ 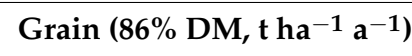 } \\
\hline & Unfertilised & Fertilised & Unfertilised & Fertilised \\
\hline Clover-grass & 12.6 & 14.3 & & \\
\hline Field bean & & & 2.4 & 2.8 \\
\hline Maize (silage) & 6.8 & 11.6 & & \\
\hline Rye (wholecrop) & 3.9 & 6.0 & & \\
\hline Soybean & & & 3.2 & 3.3 \\
\hline $\begin{array}{l}\text { Sunflower } \\
\text { (wholecrop) }\end{array}$ & 5.2 & 8.2 & & \\
\hline Triticale (wholecrop) & 6.7 & 13.0 & & \\
\hline Wheat & & & 4.2 & 6.9 \\
\hline
\end{tabular}

Soil bulk density was measured in August 2014 in block 2 and CRs 8, 10 and 1c, using intact soil cores to a depth of $5 \mathrm{~cm}$. Mean bulk density was $1.4 \mathrm{~g} \mathrm{~cm}^{-3}$ [39], which was used for the calculation of the size of SOC stocks.

\subsection{Modelling}

C input $\left(\mathrm{kg} \mathrm{ha}^{-1}\right)$ for the period 2010 to 2017 was calculated using Equation (1).

$$
C_{\text {input }}=C_{R H R}+C_{S}+C_{S F}+C_{G M}+C_{D},
$$

$\mathrm{C}_{\mathrm{RHR}}=\mathrm{C}$ input from root and harvest residues $\left(\mathrm{kg} \mathrm{ha}^{-1}\right)$

$\mathrm{C}_{\mathrm{S}}=\mathrm{C}$ input from seed $\left(\mathrm{kg} \mathrm{ha}^{-1}\right)$

$\mathrm{C}_{\mathrm{SF}}=\mathrm{C}$ input from straw fertilisation $\left(\mathrm{kg} \mathrm{ha}^{-1}\right)$

$\mathrm{C}_{\mathrm{GM}}=\mathrm{C}$ input from green manure $\left(\mathrm{kg} \mathrm{ha}^{-1}\right)$

$C_{D}=C$ input from digestate $\left(\mathrm{kg} \mathrm{ha}^{-1}\right)$.

As the $C$ content of seed was not measured, values for $C_{S}$ were taken from the REPRO model [40]. $C_{\mathrm{SF}}, \mathrm{C}_{\mathrm{GM}}$ and $\mathrm{C}_{\mathrm{D}}$ were calculated based on field trial data for yield, grain and biomass $C$ content, and digestate amount and composition data, for the period 2010-2017. $\mathrm{C}_{\mathrm{RHR}}$ was calculated using yield data and Equation (2). Equation (2) was taken from the CANDY model [34].

$$
\mathrm{C}_{\mathrm{RHR}}=\mathrm{K}_{\mathrm{RHR}}+\mathrm{F}_{\mathrm{RHR}} \times \mathrm{Y},
$$

$\mathrm{C}_{\mathrm{RHR}}=\mathrm{C}$ input from root and harvest residues $\left(\mathrm{dt} \mathrm{ha}^{-1}\right)$

$\mathrm{K}_{\mathrm{RHR}}=$ Yield-independent $\mathrm{C}$ input $\left(\mathrm{dt} \mathrm{ha}^{-1}\right)$

$\mathrm{F}_{\mathrm{RHR}}=$ Yield-dependent $\mathrm{C}$ input $\left(\mathrm{dt} \mathrm{dt}^{-1}\right)$

$\mathrm{Y}=$ Fresh matter yield $\left(\mathrm{dt} \mathrm{ha}^{-1}\right)$.

The crop parameters $K_{\text {RHR }}$ and $F_{\text {RHR }}$ (Table 4) were adapted from the CANDY model [34] as follows. The averages of the individual values for lucerne, clover and grass were used as the $K_{R H R}$ values for lucerne-clover-grass and clover-grass. The $F_{R H R}$ value for lucerne was used as the $\mathrm{F}_{\mathrm{RHR}}$ value for lucerne-clover-grass. The crop parameters for soybean, sorghum and triticale were assumed to be the same as the crop parameters for field bean, silage maize and rye, respectively. The crop parameters for wholecrop sunflower were derived from the parameters for grain sunflower, using the ratio of the parameters for grain maize and silage maize. As $C_{R H R}$ for undersown clover-grass was not available in the CANDY model, the value from REPRO was used. 
Table 4. Crop-specific $C$ input parameters $K_{R H R}, F_{R H R}$ and synthesis coefficient $S$ used to calculate $\mathrm{C}_{\mathrm{RHR}}$ and $\mathrm{C}$ input to soil organic carbon (SOC), adapted from the CANDY model [34].

\begin{tabular}{cccc}
\hline Crop & $\mathbf{K}_{\mathbf{R H R}}\left(\mathbf{d t} \mathbf{h a}^{-\mathbf{1}}\right)$ & $\mathbf{F}_{\mathbf{R H R}} \mathbf{( \mathbf { d t } _ { \mathbf { d t } } \mathbf { H } ^ { \mathbf { 1 } } )}$ & $\mathbf{S} \mathbf{( \mathbf { d t } \mathbf { d t } ^ { - \mathbf { 1 } } )}$ \\
\hline Clover-grass & 26.0 & & 0.45 \\
Cover crops & 5.0 & & 0.60 \\
Field bean & 10.0 & & 0.55 \\
Lucerne-clover-grass & 24.0 & 0.014 & 0.45 \\
Maize & 10.4 & 0.005 & 0.45 \\
Rye & 4.5 & 0.004 & 0.45 \\
Sorghum & 10.4 & 0.005 & 0.45 \\
Soybean & 10.0 & & 0.55 \\
Sunflower & 9.2 & 0.014 & 0.50 \\
Triticale & 4.5 & 0.004 & 0.45 \\
Wheat & 4.0 & 0.08 & 0.55 \\
Digestate & & & 0.60 \\
Green manure & & & 0.35 \\
Straw & & & 0.45 \\
\hline
\end{tabular}

${ }^{1}$ Sorghum instead of field bean and soybean was grown in CRs 3 and 4 prior to 2012.

The $C$ input to SOC (the $C$ that remains after respiration and therefore contributes to SOC stock) was calculated using $C_{R H R}, C_{S F}, C_{G M}$ and $C_{D}$ and the synthesis coefficients $S$ (Table 4), according to Equation (3). Equation (3) and the values for $\mathrm{S}$ were taken from the CANDY model [34].

$$
\mathrm{C}_{\text {input to SOC }}=\mathrm{C}_{\text {input }} \times \mathrm{S} \text {. }
$$

It was assumed that $C_{S}$ was used by the growing crop and therefore did not contribute to SOC stocks. The $\mathrm{S}$ for the digestate used in our field trial was assumed to be the same as the $S$ for animal-based organic fertilisers (e.g., solid or liquid manure), and the $S$ for bean straw was assumed to be the same as $\mathrm{S}$ for cereal straw.

\subsection{Statistical Analysis}

Statistical analyses were carried out using $\mathrm{R}$ version 3.5.2 [41]. To analyse the differences in SOCc between years and fertilised and unfertilised plots, a linear mixed model using restricted maximum likelihood estimation criterion (REML) with the fixed effects year, fertilisation and block was fitted. Intercepts were allowed to vary for the random effect CR field position along the $x$-axis $(n=12)$. To analyse the differences in SOCc between years and CRs, a linear mixed model using REML with the fixed effects year, CR and block was fitted, and field position of each plot along the $x$-axis was used as the random factor. A type III ANOVA with Satterthwaite degrees of freedom approximation was calculated, followed by Tukey post hoc tests of the estimated marginal means. The R packages lmer4 and emmeans were used for these analyses. A two-way factorial ANOVA was used to analyse the differences in SOCc between CRs $1 \mathrm{a}, 1 \mathrm{~b}$ and 1c, with the factors year and fertilisation. Linear regression was used to analyse the relationships between digestate fertilisation, CR components and SOCc.

\section{Results}

SOCc increased significantly from $1.10 \%$ in 2010 to $1.31 \%$ in $2017(\mathrm{t}(378)=30.94$, $p<0.001)$. This increase was significant in both the fertilised and the unfertilised plots (Table 5; for illustration see Figure 2). The increase was larger in the fertilised plots than in the unfertilised plots ( $23 \%$ versus $15 \%$ of the SOCc in 2010 ).

In 2010, six years after the start of the experiment, SOCc in the fertilised plots was $4 \%$ higher than in the unfertilised plots and, in 2017, 11\% higher, indicating that the effect had increased over time. 
Table 5. Soil organic carbon content (\%) in 2010 and 2017 (means sharing a letter are not significantly different, $p<0.001)$.

\begin{tabular}{ccc}
\hline & \multicolumn{2}{c}{ Soil Organic Carbon (\%) } \\
\cline { 2 - 3 } & $\mathbf{2 0 1 0}$ & $\mathbf{2 0 1 7}$ \\
\hline Unfertilised plots & $1.08^{\mathrm{a}}$ & $1.24^{\mathrm{c}}$ \\
Fertilised plots & $1.12^{\mathrm{b}}$ & $1.38^{\mathrm{d}}$ \\
\hline
\end{tabular}

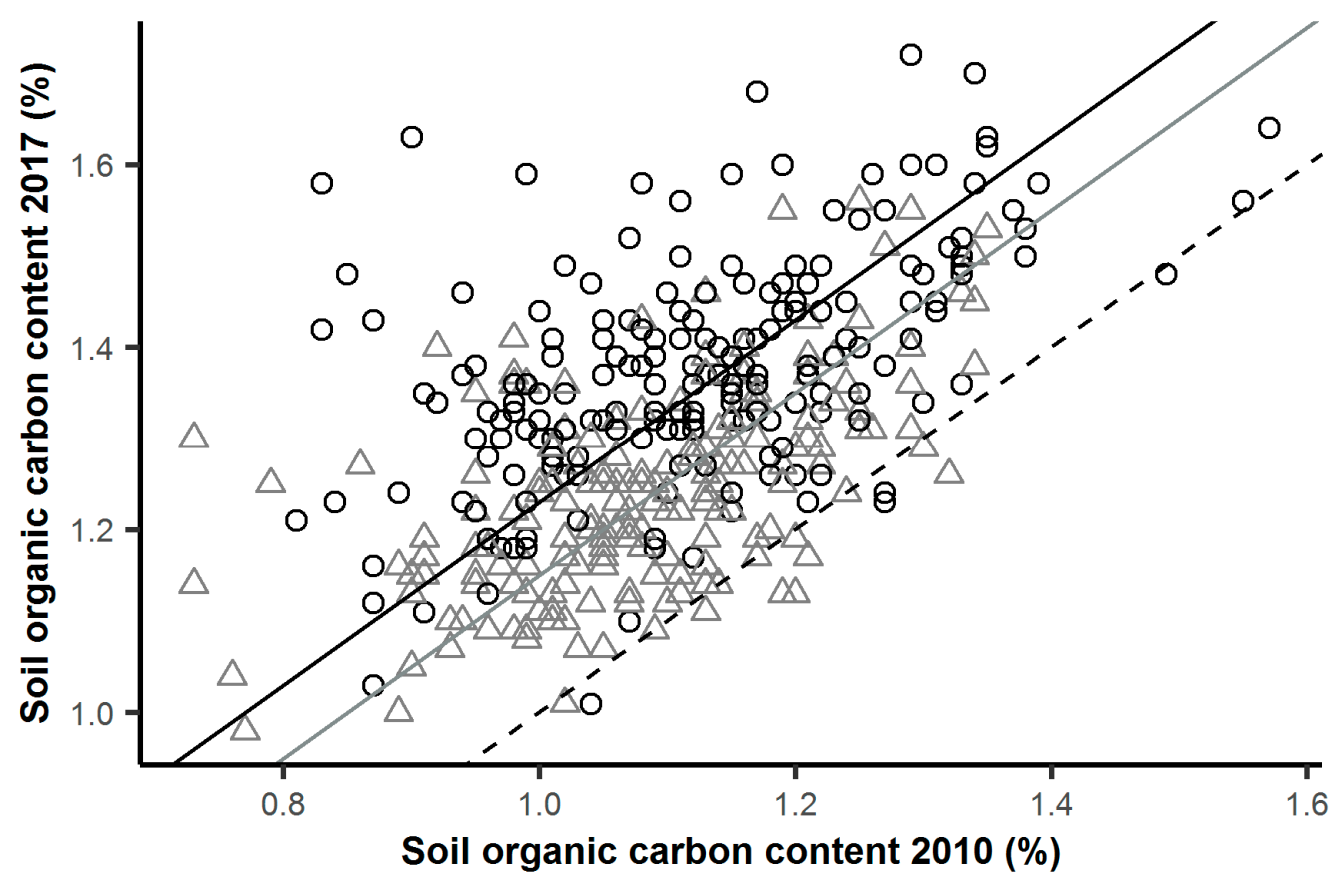

Figure 2. Correlation between SOCc (\%) in 2010 and 2017. Unfertilised plots are represented by grey triangles, fertilised plots by black circles. The dashed line is the 1:1 line. The grey line shows the mean increase for the unfertilised plots $(y=0.16+x)$ and the black line shows the mean increase for the fertilised plots $(y=0.26+x)$.

An increase occurred in nearly all plots (all data points above the 1:1 line in Figure 2) but the scatter was considerable when looking at individual (unreplicated) plots, with random variation in both the 2010 and in the 2017 measurements.

In 2010, SOCc was highest in CR6 with 50\% maize undersown with white clover in the rotation, and lowest in CR2 and CR3, both with two years of wheat in the rotation. SOCc increased significantly ( $p<0.001)$ in all CRs between 2010 and 2017 (Figure 3). In 2017 in both the fertilised and unfertilised plots, SOCc was highest in CR10, with 75\% clover-grass ley in the rotation, and lowest in CR3. Digestate fertilisation was lowest in CR3. CR10 also had the biggest increase in SOCc between 2010 and 2017 (26\%), whereas in CR4, with two years of wheat and one year of soybean in the rotation, SOCc increased by only $13 \%$. In the fertilised plots the increase was lowest in CR6; however, these plots did have the highest mean SOCc in 2010. In CR9 SOCc was 14\% higher in 2017 in the fertilised plots than in the unfertilised plots, whereas in CR4 SOCc in the fertilised plots was only $6.5 \%$ higher. CR9 received the largest amount of digestate in the experiment, whereas CR4 received the second-lowest amount. Despite this, the difference between the fertilised and unfertilised plots changed (increased) the most in CR4. In comparison, the relative difference between the fertilised and unfertilised plots stayed almost constant in CR6.

Despite identical treatment, SOCc was significantly lower in CR1a than in CR1b or CR1c in both 2010 and 2017, for both the fertilised and unfertilised plots, $p<0.01$. 


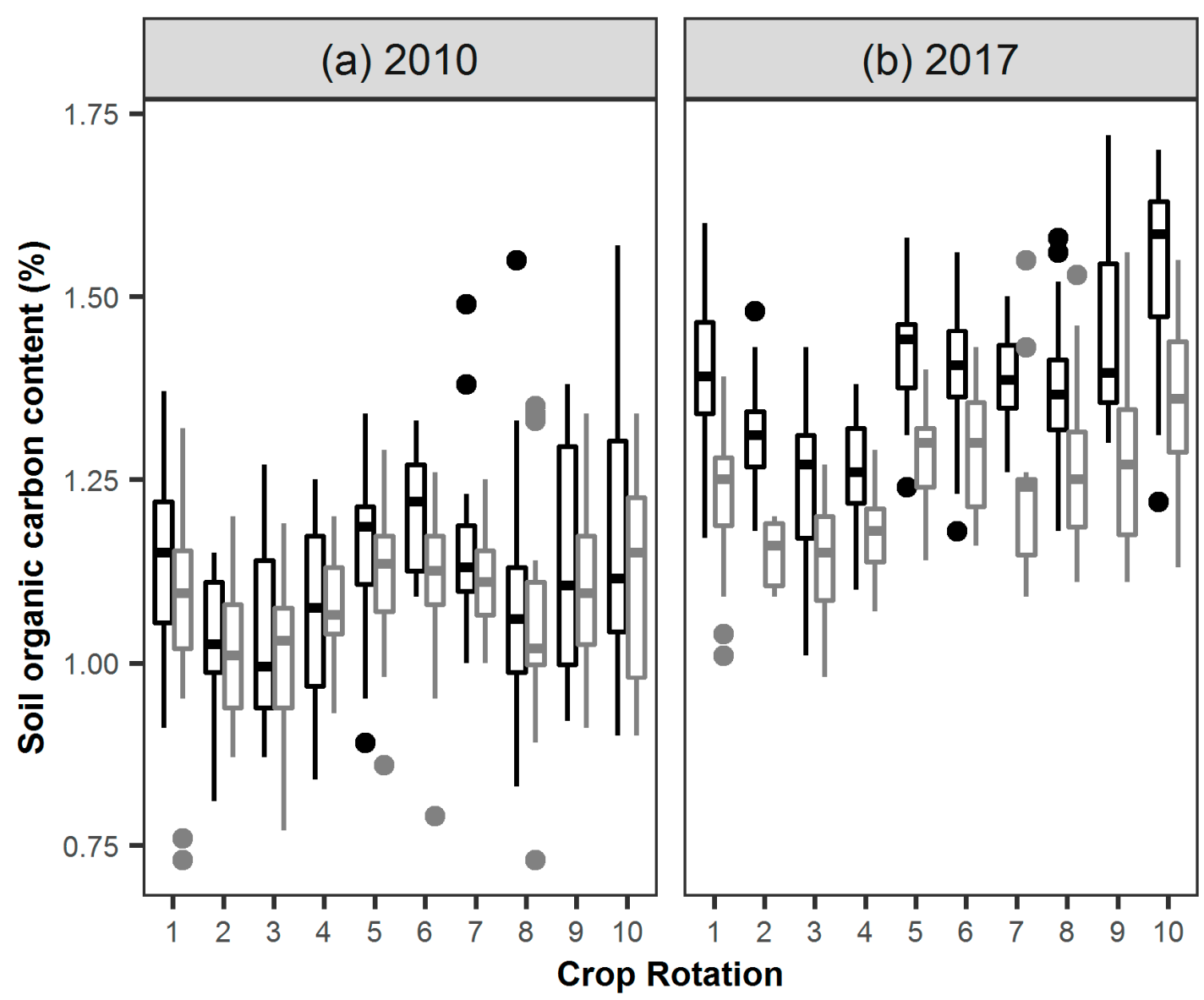

Figure 3. (a) SOCc (\%) in 2010 for each crop rotation (CR). (b) SOCc (\%) in 2017 for each CR. Unfertilised plots are represented by grey boxes, fertilised plots by black boxes ( $n=48$ for CR1, $n=16$ for all other CRs). Boxes represent the interquartile range (IQR), the line within each box represents the median, whiskers extend to a maximum of $1.5 \times \mathrm{IQR}$ beyond the box. See Table 6 for significant differences between CRs.

Table 6. Soil organic carbon content (\%) for each crop rotation (fertilised and unfertilised plots combined, $n=96$ for CR1, $n=32$ for all other CRs) in 2010 and 2017 (estimated marginal means; means sharing a letter are not significantly different, $p<0.01$ ).

\begin{tabular}{ccc}
\hline \multirow{2}{*}{ Crop Rotation } & $\mathbf{2 0 1 0}$ & $\mathbf{2 0 1 7}$ \\
\cline { 2 - 3 } & Soil Organic Carbon (\%) & Soil Organic Carbon (\%) \\
\hline CR1 & $1.11^{\mathrm{abcd}}$ & $1.32^{\mathrm{fg}}$ \\
CR2 & $1.02^{\mathrm{ab}}$ & $1.23^{\text {defg }}$ \\
CR3 & $1.00^{\mathrm{a}}$ & $1.21^{\mathrm{cdef}}$ \\
CR4 & $1.04^{\mathrm{abc}}$ & $1.25^{\mathrm{defg}}$ \\
CR5 & $1.14^{\mathrm{abcde}}$ & $1.35^{\mathrm{fg}}$ \\
CR6 & $1.15^{\mathrm{abcde}}$ & $1.35^{\mathrm{fg}}$ \\
CR8 & $1.12^{\mathrm{abcd}}$ & $1.33^{\mathrm{fg}}$ \\
CR9 & $1.09^{\mathrm{abcd}}$ & $1.30^{\mathrm{efg}}$ \\
CR10 & $1.14^{\mathrm{abcde}}$ & $1.34^{\mathrm{fg}}$ \\
\hline
\end{tabular}

There was a significant correlation between the proportion of clover-grass leys on a plot and the SOCc (Figure 4). SOCc in 2017 was higher, for both the fertilised and unfertilised plots, in those plots that had had more years of clover-grass leys. Correspondingly, CR10 (75\% clover-grass leys in the CR) and CR9 (50\% clover-grass leys in the CR) had the highest SOCc in 2017 (Figure 4). The correlation was slightly stronger for the fertilised 
plots, however the difference between the slopes of the regressions for the fertilised and unfertilised plots was not significant. This indicates that the effect of the clover-grass leys on SOCc in 2017 was independent of the effect of digestate. Using a combined slope for the fertilised and unfertilised plots and keeping the fertiliser effect constant yielded the following equation that, although it includes only two parameters, explained $44 \%$ of the variation:

$$
\text { SOCC }=1.13+1.8 \times 10^{-5} \times \mathrm{F}+0.003 \times \mathrm{L},
$$

$\mathrm{F}=$ Fertiliser total $\mathrm{C}$ amount $\left(\mathrm{kg} \mathrm{ha}^{-1}\right)$

$\mathrm{L}=$ Ley proportion $(\%)$

$R^{2}=0.44, n=379$.

Both effects were very highly significant $(p<0.001)$.

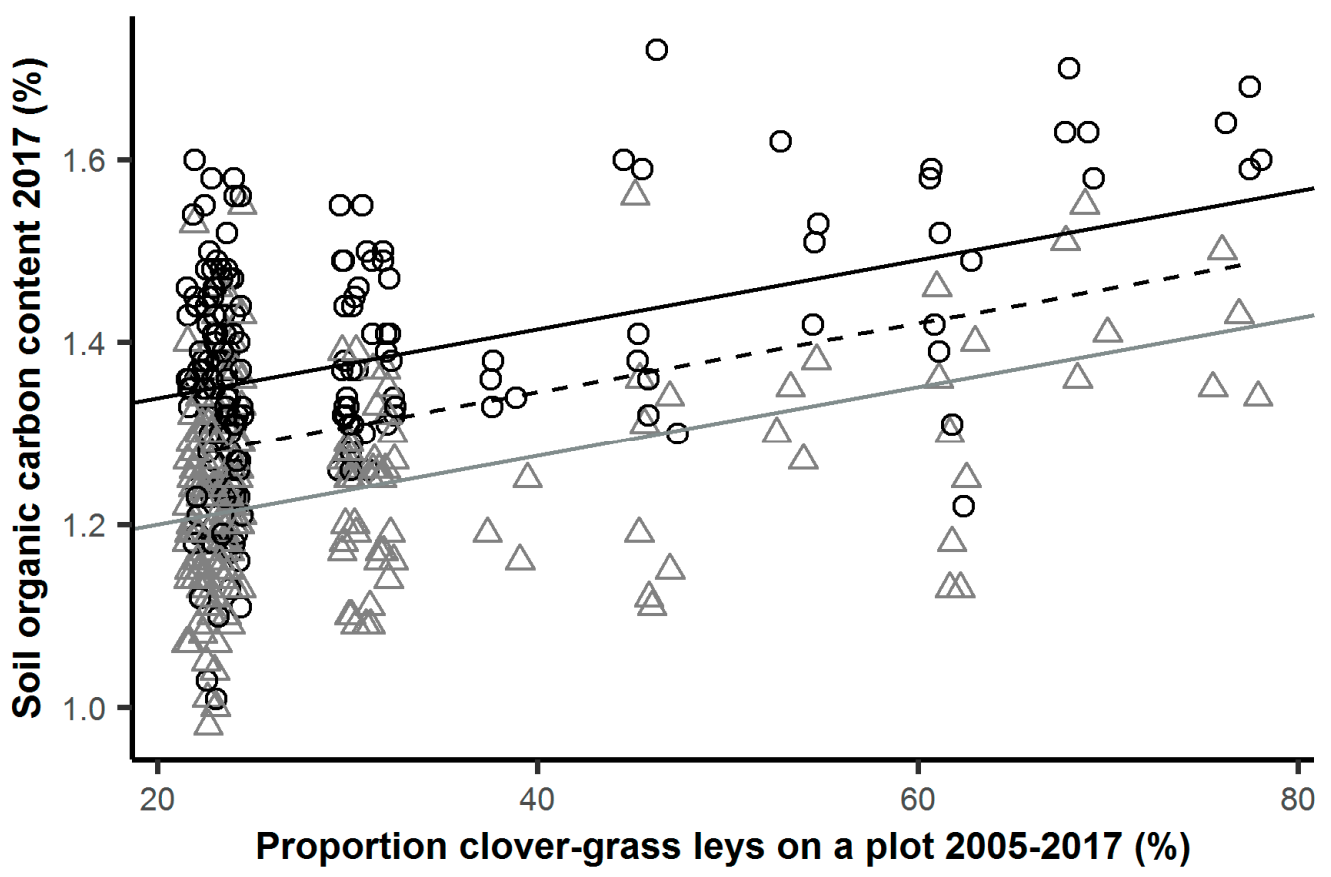

Figure 4. Correlation between the proportion of clover-grass leys on a plot in the period 20052017, and the SOCc (\%) of that plot in 2017. Unfertilised plots are represented by grey triangles, fertilised plots by black circles. The dashed line is the combined regression line $(y=1.19+0.004 x$, $\left.R^{2}=0.13, p<0.001, n=379\right)$. The grey solid line is the regression line for the unfertilised plots $(y=1.13+0.004 x)$, the black solid line is the regression line for the fertilised plots $(y=1.26+0.004 x)$, assuming no interaction between the proportion of clover-grass and fertilisation. Jitter was added to the proportion of clover-grass leys to improve visibility of symbols.

In the CRs with only one year of clover-grass there was a significant positive correlation between SOCc in 2017 and the proportion of row crops with undersown crops (Figure 5). Note that, for the sake of simplicity, we refer to the white clover in CRs 5 and 6 as an undersown crop, although the maize was sown into the clover cover crop. This correlation was significant for both the fertilised and unfertilised plots $(p<0.05)$ but again, the slopes of the regressions for the fertilised and unfertilised plots were not significantly different $(p=0.19)$. A combined slope could therefore be assumed, which resulted in the following equation:

$$
\text { SOCc }=1.21+1.7 \times 10^{-5} \times \mathrm{F}+0.002 \times \mathrm{U},
$$

$\mathrm{U}=$ Proportion undersown row crops $(\%)$

$R^{2}=0.38, n=316$. 


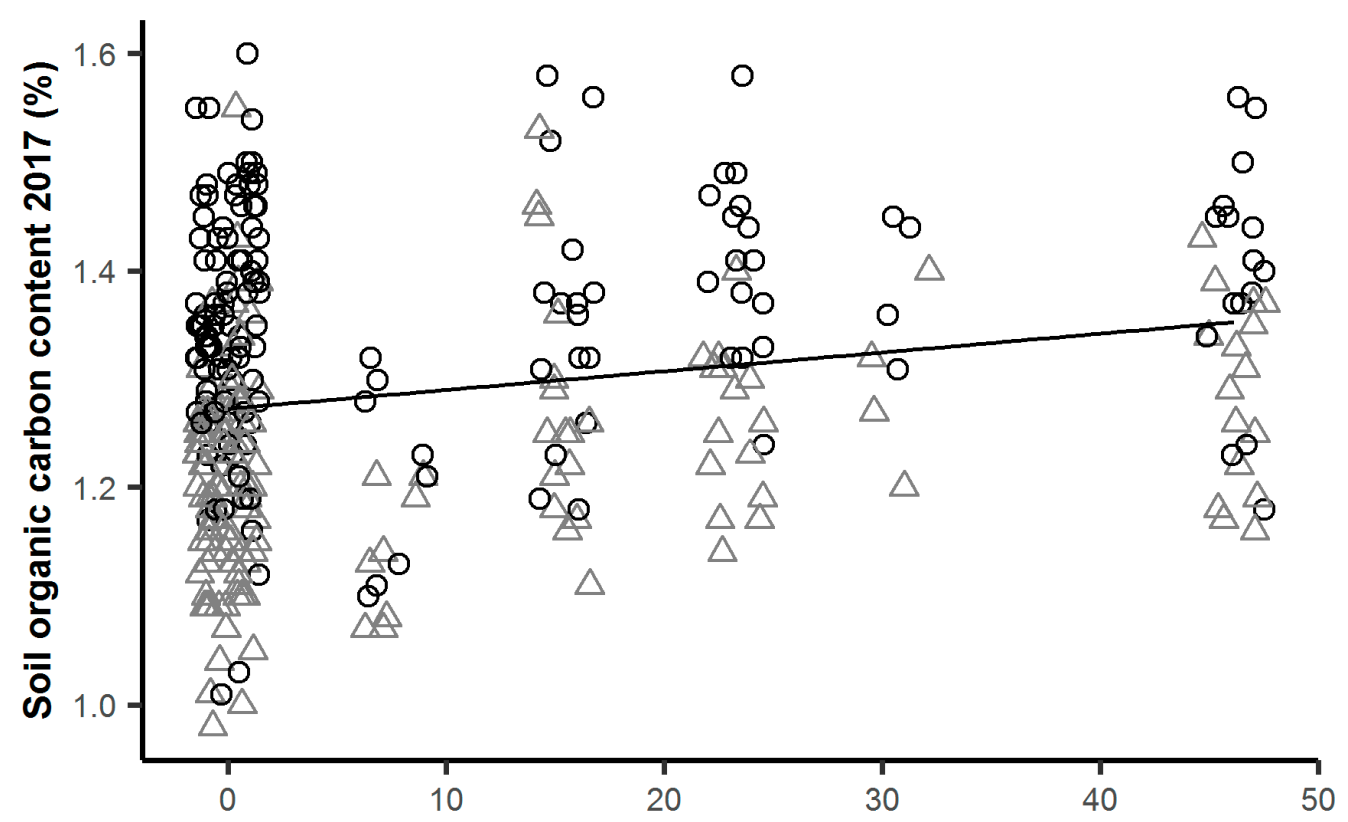

Proportion row crops with undersown crops on a plot 2005-2017 (\%)

Figure 5. Correlation between the number of years of row crops with undersown crops (white clover in maize in CR5 and CR6, clover-grass in sunflower in CR8) on a plot in the period 2005-2017, and the SOCC (\%) of that plot in 2017. Unfertilised plots are represented by grey triangles, fertilised plots by black circles. The regression line is the combined (fertilised and unfertilised) regression line $\left(\mathrm{y}=1.27+0.002 \mathrm{x}, R^{2}=0.04, p<0.001, n=316\right)$. Jitter was added to the proportion of row crops to improve visibility of symbols.

Both effects were again very highly significant $(p<0.001)$. The effect of undersown row crops was about half as strong as the effect of the clover-grass leys. The effect of fertilisation was the same for this subset of data as for the complete dataset. Combining all three influences for the complete data set yielded:

$$
\text { SOCc }=1.11+1.7 \times 10^{-5} \times \mathrm{F}+0.004 \times \mathrm{L}+0.002 \times \mathrm{U},
$$

$R^{2}=0.46, n=379$.

All effects were very highly significant $(p<0.001) . R^{2}$ indicated that these three influences explained $46 \%$ of the variation in SOCc, while $54 \%$ can be attributed to random variation and other influences (e.g., crop type, interactions).

Mean total C input, as calculated using Equation (1), was $1.98 \mathrm{t} \mathrm{ha}^{-1} \mathrm{a}^{-1}$ in the unfertilised plots and $3.17 \mathrm{t} \mathrm{ha}^{-1} \mathrm{a}^{-1}$ in the fertilised plots. Of this, $0.89 \mathrm{t} \mathrm{ha}^{-1} \mathrm{a}^{-1}$ in the unfertilised plots and $1.59 \mathrm{t} \mathrm{ha}^{-1} \mathrm{a}^{-1}$ in the fertilised plots were estimated, according to Equation (3), to have been added to SOC. In the unfertilised plots, nearly $90 \%$ of the total $\mathrm{C}$ input was from crop residues and roots. In the fertilised plots, $60 \%$ of the total C input came from crop residues and roots, and $33 \%$ from digestate fertilisation.

C inputs, both total and input to SOC, were highest when clover-grass was grown, due to crop residues and roots. Consequently, the calculated $C$ input was highest for CR10, with $75 \%$ clover-grass in the rotation. Row crops such as maize and sunflower were calculated as having higher $\mathrm{C}$ inputs than wheat or triticale. CR8 therefore had the third-highest (after CRs 9 and 10) C inputs of the fertilised plots, particularly as the sunflower crop was undersown with clover-grass. CR3, with two years of wheat in the rotation, had the lowest $\mathrm{C}$ input of the fertilised plots. $\mathrm{C}$ inputs from digestate were highest in CRs 9 and 1, and lowest in CRs 3 and 4. The relationship between the estimated C input to SOC per crop rotation and the change in SOC for that crop rotation was very highly significant (Figure 6) and close to the 1:1 line, even without model calibration. Note that, in particular, the data points for $\mathrm{CRs} 1 \mathrm{a}, 1 \mathrm{~b}$ and $1 \mathrm{c}$ are close together, for both the fertilised and unfertilised plots. 
These CRs were identical but differed in their positions within the experimental site. Their initial SOCc spanned the whole range of values for all CRs. This indicates that initial SOCc had no influence on either the calculated or measured change in SOC stocks.

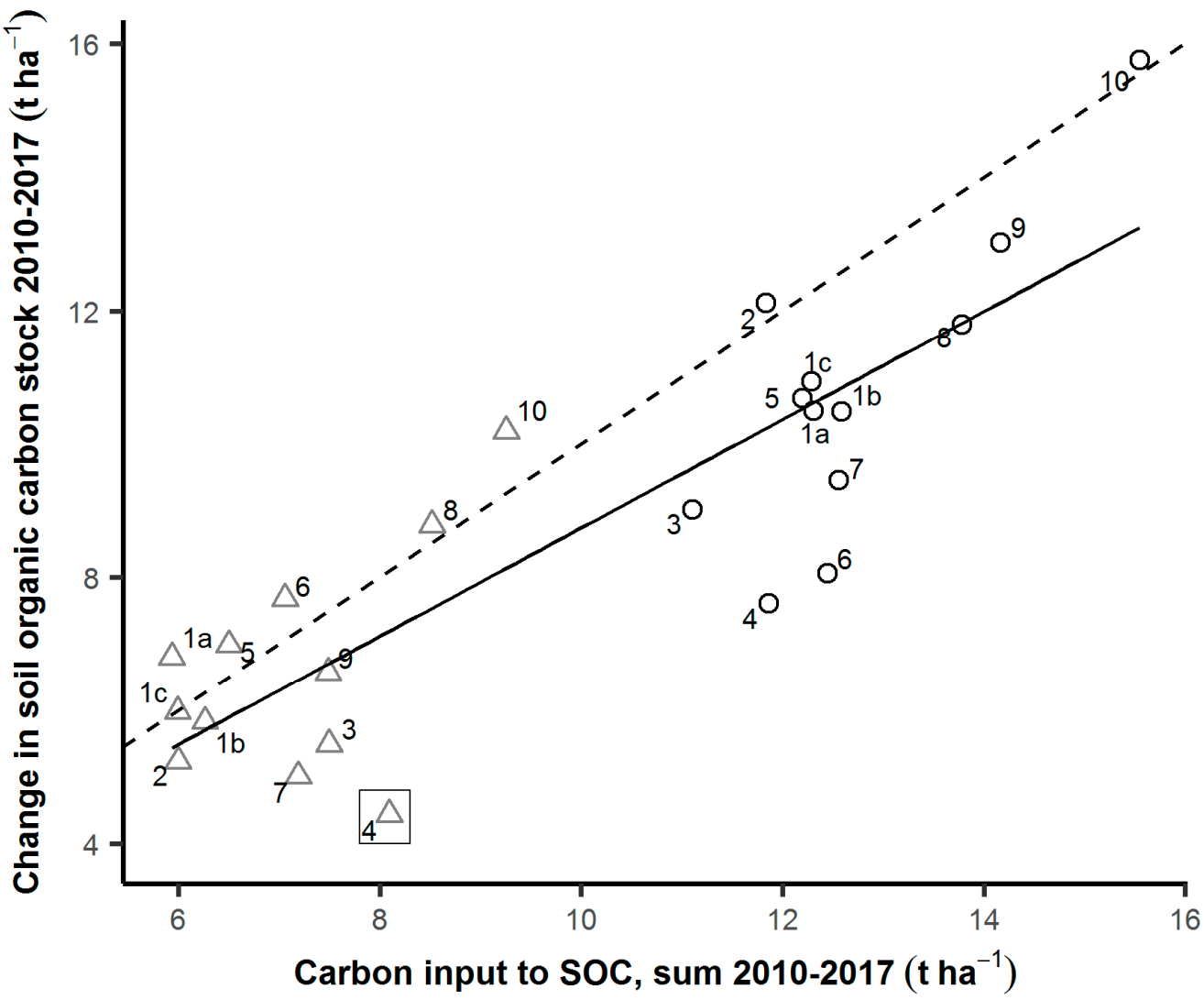

Figure 6. Correlation between estimated total (sum) $\mathrm{C}$ input to SOC $\left(\mathrm{t} \mathrm{ha}{ }^{-1}\right.$ ) for each $\mathrm{CR}$ in the period 2010-2017, and the measured change in SOC stock ( $\mathrm{t} \mathrm{ha}^{-1}$ ) of that CR between 2010 and $2017(n=24)$. Each data point is the mean of 16 plots to reduce propagation of uncertainty resulting from the subtraction of the SOC stock in 2010 from the SOC stock in 2017. Unfertilised plots are represented by grey triangles, fertilised plots by black circles. The number next to a data point is the $\mathrm{CR}$. The solid line is the regression line $\left(\mathrm{y}=0.61+0.81 \mathrm{x}, R^{2}=0.74, p<0.001, n=24\right)$. The dashed line is the 1:1 line. The data point marked with a square is an outlier (CR4 unfertilised plots).

Estimated C inputs to SOC varied between 5.9 and $15.5 \mathrm{tha}^{-1}$ depending on the CR and fertilisation, whereas the measured changes in SOC stocks ranged between 4.4 and $15.8 \mathrm{t} \mathrm{ha}^{-1}$. The data indicated that the increase in SOC stocks was, on average, $1.3 \mathrm{tha}^{-1}$ less than the calculated amount of $\mathrm{C}$ added to the SOC stocks. The data points for both the fertilised and unfertilised plots for CR10, which had the highest proportion of clover-grass leys (three out of four years), were close to the 1:1 line, indicating that the $C$ inputs for clover-grass were predicted correctly by the model. This was corroborated by CR9, with the second-highest proportion of clover-grass leys in the rotation (two out of four years). The data points for CR9 arranged only slightly below the 1:1 line. CRs 4 and 7, and to a lesser extent CR3, deviated most. These three CRs all had a legume/non-legume cover crop in common. However, CR8 also had a legume/non-legume cover crop but the results for this CR corresponded with the modelled values.

\section{Discussion}

The majority of studies to date investigating the effects of farm biogas production on soils have either been pot experiments or short-term conventional field experiments. Our study is based on data from a long-term field trial run according to organic principles 
and, as such, biogas production on the basis of clover-grass leys. It is also one of the few biogas field trials where the amount of digestate applied is based on nutrient cycling, i.e., on the estimated yield of the respective crop rotation, and which therefore represents more realistic conditions [26].

Even though the experiment had already been running for five years before the data we used in this study were collected, SOCc still increased in $96 \%$ of plots, irrespective of the CR or if plots were fertilised or not. This effect was particularly remarkable for the unfertilised plots, given that nearly all aboveground biomass had been removed for 13 years and there was no nutrient return in the form of fertilisation.

Our regression model showed that this was due to the effects of the clover-grass leys and the undersown row crops. If there were no fertilisation, clover-grass leys or undersown row crops (i.e., if F, L and U were equal to zero in Equation (6)), then our regression model would result in an SOCc of 1.11\%, which is very close to the mean SOCc of $1.10 \%$ in 2010.

This effect was found across CRs and site position, and therefore any variation in soil properties. Our modelling of the C input to SOC corroborated these results and showed that an increase in SOCc based on these effects is feasible. Our results also corresponded with results from an earlier period (2010-2014) [42].

Increasing the proportion of row crops undersown with clover or clover-grass by $10 \%$ would increase SOCc by $0.02 \%$, according to our regression model. Although only three out of 12 CRs included undersown row crops (up until 2012 CR4 also included sunflower undersown with clover-grass), the plots in these CRs still represented a wide range of differing proportions of undersown row crops. Aside from the positive effects of clover and clover-grass on SOC, undersowing row crops means more vegetation cover, which leads to more $C$ input from roots and, in our field trial, from shoot biomass when the undersown crops were mulched. Yields of the undersown clover and clover-grass were similar in both the fertilised and unfertilised plots (data unpublished); however, yields of the main crops were lower in the unfertilised plots. Maize yields, for example, were $70 \%$ higher in the fertilised plots than in the unfertilised plots. When $\mathrm{N}$ is limited, crops tend to allocate more resources to the roots than aboveground biomass [43] and the root:shoot ratio increases. Nonetheless, it is likely that due to the large differences in aboveground biomass, root systems of the main crops were smaller in the unfertilised plots. The undersown crops in the unfertilised plots could therefore have produced more belowground biomass, as there was less competition for space and nutrients. Cong et al. [44], for example, found that although undersown legume-grass leys produced less aboveground biomass in unfertilised plots, there was no difference in root biomass between fertilised and unfertilised plots.

Fertilisation with digestate had the biggest effect on SOCc. In addition to the direct effect of the digestate itself on SOC, fertilisation increased yields in our trial, meaning $C$ input from root and harvest residues was modelled as being higher in the fertilised plots. The effect of digestate fertilisation on root growth is, however, at present unclear, particularly as most studies to date have been pot experiments and data from field trials is lacking. Digestate fertilisation increased the root biomass of wheat in a field trial [45] and grass in a pot experiment [46], but in other pot experiments digestate fertilisation either had no effect [47] or inhibited root growth of grasses [48]. If both the solid and liquid phases of the digestate had been used instead of just the liquid phase as in our field trial, the effect on SOCc would have been even greater according to Equation (6), given the larger amount of $C$ applied to the soil $[49,50]$. Further research would, however, be needed to ascertain if Equation (6) also applies to the solid digestate phase.

The highest inputs to SOC from crops in our field trial were when clover-grass was grown. CR10, with 75\% clover-grass in the rotation, had the highest SOCc and the largest increase in SOCc between 2009 and 2017, which agrees with the finding that increasing the proportion of leys in organic CRs (also in combination with organic fertilisers) increased SOCc [28]. This increase seemed to be constant, even over a 13-year period, with an increase of $0.004 \%$ in SOCc when the proportion of clover-grass leys in the CR was increased by $1 \%$. Given that in most rotations there was only one year of clover-grass, whereas with $75 \%$ 
clover-grass ley in CR10 there was no tillage in these plots for three of the four years of the $\mathrm{CR}$, this indicated that tillage did not have an important influence on this effect, although it is often assumed that tillage destroys soil aggregates and exposes the SOC protected in these aggregates to mineralisation, increasing decomposition rates [51]. An important implication of the linear increase of SOCc with the proportion of clover-grass in the CR is that the length of the period between clover-grass years seemed to be of minor importance and did not cause any substantial loss of SOC. The longest break between clover-grass years was only three years in our field trial, and hence this inference is restricted to a rather short period, but given that turnover is always highest in the first few years, a low degradation rate can be expected to last longer. Freibauer et al. [52] estimated that increasing the duration of leys would lead to an increase in the potential SOC accumulation rate of $0.1-0.5 \mathrm{tha}^{-1} \mathrm{a}^{-1}$. Our results are consistent with this estimate. Using the average bulk density to calculate $C$ stocks, the plots in CR10 accumulated $1.58 \mathrm{t} \mathrm{ha}^{-1} \mathrm{a}^{-1}$. In comparison, the plots with only one year of clover-grass ley accumulated $1.26 \mathrm{tha}^{-1} \mathrm{a}^{-1}$, a difference of $0.32 \mathrm{t} \mathrm{ha}^{-1} \mathrm{a}^{-1}$. It is important to note, however, that in CR10 ley composition changed over time, with the proportion of grass increasing, and total yield decreasing, by the third year (data unpublished). Nevertheless, we have not had any disease or pest problems in this or any of the other rotations, despite the short break between leys.

As our regressions suggest that any addition of ley to a rotation will increase SOCc, for the CRs with only $25 \%$ clover-grass leys in the rotation and no undersown row crops, it appears that the $\mathrm{C}$ input from the root and harvest residues from these leys was enough to increase SOCc, even without additional fertilisation. Models have estimated that $\mathrm{C}$ inputs of $1.5 \mathrm{t}$ are enough to maintain SOC $[53,54]$. This is lower than the mean $\mathrm{C}$ input of $1.8 \mathrm{t} \mathrm{ha}^{-1} \mathrm{a}^{-1}$ in these unfertilised plots, which could explain why SOCc did not decrease in these plots.

The correlation between the measured change in SOC and the estimated $\mathrm{C}$ input to SOC indicated an average respiration rate of $0.3 \%$ per year. This is lower than the mineralisation rates normally seen for arable soils [55]. Our model could therefore have underestimated the $\mathrm{C}$ input to SOC. The crop parameters we used were developed for conventionally-grown crops; however, it has been shown that root:shoot ratios are higher for organically-grown crops, presumably due to lower nutrient (particularly $\mathrm{N}$ ) availability [56]. This would also explain why the difference between the measured change in SOC and the estimated $C$ input for the unfertilised plots was smaller than for the fertilised plots, and why the measured change was higher than the $C$ inputs in nearly half of the CRs for the unfertilised plots. However, increasing the yield-dependent parameter $F_{R H R}$ to take into account higher root biomass at lower yields in organic crops would only have a small effect on the estimated C input to SOC, as the parameter $\mathrm{K}_{\mathrm{RHR}}$ generally makes up a much larger proportion of the calculated C input to SOC. As $\mathrm{K}_{\mathrm{RHR}}$ is a constant independent of yield, this already allocates a larger proportion of biomass to belowground biomass at low yields.

Alternatively, it could be that the mineralisation rates in these plots were so low that barely any $\mathrm{C}$ was lost due to mineralisation, and therefore the $\mathrm{C}$ input to SOC was roughly equal to the increase in SOC. In CR10 with 75\% clover-grass in the rotation, for example, in both the fertilised and unfertilised plots the measured change in SOC was greater than the estimated C input. Acharya et al. [57] found that mineralisation rates were lower in the second and third years of leys than in the first year, and that root biomass increased with ley age. This was not taken into account in our model (we used the same crop parameters for all leys), and therefore our estimated C input to SOC could have been too low for CR10.

The unfertilised plots in CR4 were an outlier in this correlation, with a much lower increase in SOC than predicted by the level of $C$ inputs. This CR includes soybean, which is a relatively new crop in Germany. We assumed the same crop parameters for soybean as for field bean, which is a well-established crop in Germany. However, despite higher yields for soybean in our field trial than for field bean, it could be that, under German conditions, the harvest and root residues are lower. Nonetheless, reducing $\mathrm{K}_{\mathrm{RHR}}$ and the synthesis 
coefficient for soybean in our model, or even removing this CR from our model entirely, did not change the slope of the regression and only increased $R^{2}$ to 0.80 .

Differences in yields and SOC between CRs $1 \mathrm{a}, \mathrm{b}$ and c, despite identical treatment, indicate that there could be soil heterogeneity across the site. Further analysis of $\mathrm{pH}$ values indicated the presence of carbonates in a distinct pattern across the site. Analysis of historical records showed the presence of an old road running through the field trial. Although the 2017 soil samples were reanalysed depending on $\mathrm{pH}$, this was not the case for the 2009 samples. Removing carbonates from the 2009 samples would have lowered the SOC values for these plots, and would make the difference between SOCc in 2010 and 2017 even larger. A preliminary analysis indicated, however, that it would not change the results of modelling [58]. This needs to be taken into account in the future when samples are analysed. However, this possible heterogeneity also means that our results would be valid for a wide range of initial soil conditions.

The effects of the three predictors in our regression were additive, also over time. This means our results can be applied to a broad range of situations. For example, if there are no undersown crops in the $C R$ (i.e., $U=0$ in Equation (6)), the effects of the leys on SOCc will still remain the same. Our regressions show farmers how increasing the proportion of clover-grass and/or undersown crops in their CRs will impact SOCc. The regressions can therefore also be used by governments when planning subsidy schemes for farmers with the aim of improving SOCc (for example, for $\mathrm{C}$ sequestration and climate change mitigation). Our additive model also means that separate subsidies could be paid for each of our three variables, so even if farmers only include one of our variables in their farming, they would still increase SOCc and could also receive a subsidy. Our results hold true for a period of at least ten years, which is a longer period than most farmers plan for and is longer than the duration of most farm subsidy schemes.

In the CANDY model, calculating the $\mathrm{C}$ input to SOC is also additive, where the $C$ input from various sources is simply added together. CANDY is based on data from long-term field experiments. Despite possible sources of error, such as assuming that bulk density was the same for all plots and very simply adapting the crop parameters, our model correlated well with our measured data. This corroborates that a simple additive model based on long-term field trial data can be used to predict changes in SOCc.

\section{Conclusions}

Our long-term experiment showed that clover-grass leys have a remarkably positive effect on SOCc, increasing it by $0.004 \%$ for every year a ley is grown, even if the aboveground biomass is removed for renewable energy production and not returned as organic fertiliser. Returning the nutrients and part of the organic matter as biogas digestate increased biomass production and, in turn, SOCc even further, by $0.017 \%$ for every $1 \mathrm{t} \mathrm{ha}^{-1}$ of digestate $C$ applied. When row crops were undersown with clover or clover-grass this also had a positive effect on SOCc, increasing it by $0.002 \%$ every year undersown crops were grown. Digestate fertilisation gives organic farmers the opportunity to control the timing and quantity of $\mathrm{N}$ fertilisation, improving yields of other crops and hence increasing $\mathrm{C}$ inputs to soil. Our results therefore support scenarios for sustainable farming involving the anaerobic digestion of agricultural feedstocks such as ley and crop biomass.

Author Contributions: Conceptualization, K.A. and K.S.L.; methodology, K.A.; validation, K.A.; formal analysis, K.S.L.; investigation, H.J.R.; resources, K.-J.H.; data curation, K.S.L.; writing-original draft preparation, K.S.L.; writing-review and editing, K.A., K.-J.H. and H.J.R.; visualization, K.S.L.; supervision, K.A., H.J.R. and K.-J.H.; project administration, H.J.R. and K.-J.H.; funding acquisition, H.J.R. and K.-J.H. All authors have read and agreed to the published version of the manuscript.

Funding: Data collection in the field trial for the period 2013-2016 was funded by the Bavarian State Ministry for Food, Agriculture and Forestry, as part of the project BOFRUBIOGAS.

Data Availability Statement: The data presented in this study are available on request from the corresponding author. 
Acknowledgments: The authors would like to thank Stefan Kimmelmann and his team for their hard work managing the field trial for the last 15 years. The authors would also like to thank Stephan Haug from TUMIStat for his assistance with the linear mixed models used in this paper. K. Levin would like to thank Harald Schmid for his advice on calculating $\mathrm{C}$ inputs and Marvin Melzer for his work on the $\mathrm{C}$ input model.

Conflicts of Interest: The authors declare no conflict of interest.

\section{References}

1. Council Regulation (EC) No 834/2007 of 28 June 2007 on Organic Production and Labelling of Organic Products and Repealing Regulation (EEC) No 2092/91. Available online: https:/ / eur-lex.europa.eu/eli/reg/2007/834/oj (accessed on 10 July 2021).

2. Dahlin, S.; Kirchmann, H.; Kätterer, T.; Gunnarsson, S.; Bergström, L. Possibilities for improving nitrogen use from organic materials in agricultural cropping systems. AMBIO 2005, 34, 288-295. [CrossRef] [PubMed]

3. Berry, P.M.; Stockdale, E.A.; Sylvester-Bradley, R.; Philipps, L.; Smith, K.A.; Lord, E.I.; Watson, C.A.; Fortune, S. N, P and K budgets for crop rotations on nine organic farms in the UK. Soil Use Manag. 2003, 19, 112-118. [CrossRef]

4. Lal, R. Soil carbon sequestration impacts on global climate change and food security. Science 2004, 304, 1623-1627. [CrossRef] [PubMed]

5. Aubert, P.-M.; Schwoob, M.-H.; Poux, X. Agroecology and Carbon Neutrality in Europe by 2050: What Are the Issues? Findings from the TYFA Modelling Exercise; Study 02/19; IDDRI: Paris, France, 2019.

6. Sanders, J.; Klöble, U. Ökologischer Landbau in Deutschland. In Faustzahlen für den Ökologischen Landbau, new ed.; Kuratorium für Technik und Bauwesen in der Landwirtschaft: Darmstadt, Germany, 2015; pp. 23-39, ISBN 9783945088050.

7. Serdjuk, M.; Bodmer, U.; Hülsbergen, K.-J. Integration of biogas production into organic arable farming systems: Crop yield response and economic effects. Org. Agr. 2018, 8, 301-314. [CrossRef]

8. Möller, K.; Stinner, W. Effects of different manuring systems with and without biogas digestion on soil mineral nitrogen content and on gaseous nitrogen losses (ammonia, nitrous oxides). Eur. J. Agron. 2009, 30, 1-16. [CrossRef]

9. Heuwinkel, H. Symbiontische $\mathrm{N}_{2}$-Fixierung im ökologischen Landbau: Ansätze zur Verbesserung der Schätzwerte. In Bewertung ökologischer Betriebssysteme: Bodenfruchtbarkeit, Stoffkreisläufe, Biodiversität; Kuratorium für Technik und Bauwesen in der Landwirtschaft, e.V., Ed.; KTBL: Darmstadt, Germany, 2007; pp. 70-83, ISBN 9783939371342.

10. Möller, K.; Müller, T. Effects of anaerobic digestion on digestate nutrient availability and crop growth: A review. Eng. Life Sci. 2012, 12, 242-257. [CrossRef]

11. Berry, P.M.; Sylvester-Bradley, R.; Philipps, L.; Hatch, D.J.; Cuttle, S.P.; Rayns, F.W.; Gosling, P. Is the productivity of organic farms restricted by the supply of available nitrogen? Soil Use Manag. 2002, 18, 248-255. [CrossRef]

12. Kong, A.Y.Y.; Six, J.; Bryant, D.C.; Denison, R.F.; van Kessel, C. The relationship between carbon input, aggregation, and soil organic carbon stabilization in sustainable cropping systems. Soil Sci. Soc. Am. J. 2005, 69, 1078-1085. [CrossRef]

13. Enríquez, S.; Duarte, C.M.; Sand-Jensen, K. Patterns in decomposition rates among photosynthetic organisms: The importance of detritus C:N:P content. Oecologia 1993, 94, 457-471. [CrossRef] [PubMed]

14. Zhang, D.; Hui, D.; Luo, Y.; Zhou, G. Rates of litter decomposition in terrestrial ecosystems: Global patterns and controlling factors. J. Plant Ecol. 2008, 1, 85-93. [CrossRef]

15. Hatton, P.-J.; Castanha, C.; Torn, M.S.; Bird, J.A. Litter type control on soil C and N stabilization dynamics in a temperate forest. Glob Chang Biol. 2015, 21, 1358-1367. [CrossRef] [PubMed]

16. Risberg, K.; Cederlund, H.; Pell, M.; Arthurson, V.; Schnürer, A. Comparative characterization of digestate versus pig slurry and cow manure-Chemical composition and effects on soil microbial activity. Waste Manag. 2017, 61, 529-538. [CrossRef] [PubMed]

17. Alburquerque, J.A.; de la Fuente, C.; Bernal, M.P. Chemical properties of anaerobic digestates affecting C and N dynamics in amended soils. Agr. Ecosyst. Environ. 2012, 160, 15-22. [CrossRef]

18. Coban, H.; Miltner, A.; Elling, F.J.; Hinrichs, K.-U.; Kästner, M. The contribution of biogas residues to soil organic matter formation and $\mathrm{CO}_{2}$ emissions in an arable soil. Soil Biol. Biochem. 2015, 86, 108-115. [CrossRef]

19. Ernst, G.; Müller, A.; Göhler, H.; Emmerling, C. C and N turnover of fermented residues from biogas plants in soil in the presence of three different earthworm species (Lumbricus terrestris, Aporrectodea longa, Aporrectodea caliginosa). Soil Biol. Biochem. 2008, 40, 1413-1420. [CrossRef]

20. Manyi-Loh, C.E.; Mamphweli, S.N.; Meyer, E.L.; Okoh, A.I. Microbial anaerobic digestion: Process dynamics and implications from the renewable energy, environmental and agronomy perspectives. Int. J. Environ. Sci. Technol. 2019, 16, 3913-3934. [CrossRef]

21. Ahlberg-Eliasson, K.; Liu, T.; Nadeau, E.; Schnürer, A. Forage types and origin of manure in codigestion affect methane yield and microbial community structure. Grass Forage Sci. 2018, 73, 740-757. [CrossRef]

22. Wentzel, S.; Joergensen, R.G. Quantitative microbial indices in biogas and raw cattle slurries. Eng. Life Sci. 2016, 16, 231-237. [CrossRef]

23. Thomsen, I.K.; Olesen, J.E.; Møller, H.B.; Sørensen, P.; Christensen, B.T. Carbon dynamics and retention in soil after anaerobic digestion of dairy cattle feed and faeces. Soil Biol. Biochem. 2013, 58, 82-87. [CrossRef]

24. Tambone, F.; Scaglia, B.; D’Imporzano, G.; Schievano, A.; Orzi, V.; Salati, S.; Adani, F. Assessing amendment and fertilizing properties of digestates from anaerobic digestion through a comparative study with digested sludge and compost. Chemosphere 2010, 81, 577-583. [CrossRef] 
25. Insam, H.; Gómez-Brandón, M.; Ascher, J. Manure-based biogas fermentation residues-Friend or foe of soil fertility? Soil Biol. Biochem. 2015, 84, 1-14. [CrossRef]

26. Möller, K. Effects of anaerobic digestion on soil carbon and nitrogen turnover, $\mathrm{N}$ emissions, and soil biological activity. A review. Agron. Sustain. Dev. 2015, 35, 1021-1041. [CrossRef]

27. Stockdale, E.A.; Lampkin, N.H.; Hovi, M.; Keatinge, R.; Lennartsson, E.K.M.; Macdonald, D.W.; Padel, S.; Tattersall, F.H.; Wolfe, M.S.; Watson, C.A. Agronomic and environmental implications of organic farming systems. Adv. Agron. 2001, 70, $261-327$.

28. Jarvis, N.; Forkman, J.; Koestel, J.; Kätterer, T.; Larsbo, M.; Taylor, A. Long-term effects of grass-clover leys on the structure of a silt loam soil in a cold climate. Agr. Ecosyst. Environ. 2017, 247, 319-328. [CrossRef]

29. Soussana, J.-F.; Loiseau, P.; Vuichard, N.; Ceschia, E.; Balesdent, J.; Chevallier, T.; Arrouays, D. Carbon cycling and sequestration opportunities in temperate grasslands. Soil Use Manag. 2004, 20, 219-230. [CrossRef]

30. Loges, R.; Bunne, I.; Reinsch, T.; Malisch, C.; Kluß, C.; Herrmann, A.; Taube, F. Forage production in rotational systems generates similar yields compared to maize monocultures but improves soil carbon stocks. Eur. J. Agron. 2018, 97, 11-19. [CrossRef]

31. Börjesson, P.; Prade, T.; Lantz, M.; Björnsson, L. Energy crop-based biogas as vehicle fuel—the impact of crop selection on energy efficiency and greenhouse gas performance. Energies 2015, 8, 6033-6058. [CrossRef]

32. Brandão, M.; Milà i Canals, L.; Clift, R. Soil organic carbon changes in the cultivation of energy crops: Implications for GHG balances and soil quality for use in LCA. Biomass Bioenergy 2011, 35, 2323-2336. [CrossRef]

33. Prays, N.; Dominik, P.; Sänger, A.; Franko, U. Biogas residue parameterization for soil organic matter modeling. PLoS ONE 2018, 13, e0204121. [CrossRef] [PubMed]

34. Franko, U. Modellierung des Umsatzes der organischen Bodensubstanz. Arch. Agron. Soil Sci. 1997, 41, 527-547. [CrossRef]

35. Johnston, A.E.; Poulton, P.R. The importance of long-term experiments in agriculture: Their management to ensure continued crop production and soil fertility; the Rothamsted experience. Eur. J. Soil Sci. 2018, 69, 113-125. [CrossRef] [PubMed]

36. Soil Survey Staff. Illustrated Guide to Soil Taxonomy, Version 2.0; U.S. Department of Agriculture, Natural Resources Conservation Service, National Soil Survey Center: Lincoln, NE, USA, 2015.

37. IUSS Working Group WRB. World Reference Base for Soil Resources 2014: International Soil Classification System for Naming Soils and Creating Legends for Soil Maps; FAO: Rome, Italy, 2014; ISBN 978-92-5-108369-7.

38. Verband Deutscher Landwirtschaftlicher Untersuchungs- und Forschungsanstalten. Die Untersuchung von Böden, 4th ed.; VDLUFA-Verlag: Darmstadt, Germany, 2016; ISBN 978-3-941273-21-4.

39. Reents, H.J.; Simon, A.; Levin, K.; Hülsbergen, K.-J. Wirkungen von Biogassystemen auf Bodenfruchtbarkeit, Ertrag und Produktqualität unter den Bedingungen des ökologischen Landbaus: BOFRUBIOGAS; Project Report; Technische Universität München: Freising, Germany, 2018.

40. Küstermann, B.; Kainz, M.; Hülsbergen, K.-J. Modeling carbon cycles and estimation of greenhouse gas emissions from organic and conventional farming systems. Renew. Agr. Food Syst. 2008, 23, 38-52. [CrossRef]

41. R Core Team. R: A Language and Environment for Statistical Computing; R Foundation for Statistical Computing: Vienna, Austria, 2018.

42. Simon, A.I.L. Langzeitwirkungen von Gärresten in Energiepflanzenfruchtfolgen auf Bodeneigenschaften und Bodenprozesse unter den Bedingungen des ökologischen Landbaus, 1st ed.; Verlag Dr. Köster: Berlin, Germany, 2021; ISBN 9783968310138.

43. Meurer, K.H.E.; Bolinder, M.A.; Andrén, O.; Hansson, A.-C.; Pettersson, R.; Kätterer, T. Shoot and root production in mixed grass ley under daily fertilization and irrigation: Validating the $\mathrm{N}$ productivity concept under field conditions. Nutr. Cycl. Agroecosys. 2019, 115, 85-99. [CrossRef]

44. Cong, W.-F.; Christensen, B.T.; Eriksen, J. Soil nutrient levels define herbage yield but not root biomass in a multispecies grass-legume ley. Agr. Ecosyst. Environ. 2019, 276, 47-54. [CrossRef]

45. Garg, R.N.; Pathak, H.; Das, D.K.; Tomar, R.K. Use of flyash and biogas slurry for improving wheat yield and physical properties of soil. Environ. Monit. Assess. 2005, 107, 1-9. [CrossRef] [PubMed]

46. Gunnarsson, A.; Bengtsson, F.; Caspersen, S. Use efficiency of nitrogen from biodigested plant material by ryegrass. J. Plant Nutr. Soil Sci. 2010, 173, 113-119. [CrossRef]

47. Wentzel, S.; Joergensen, R.G. Effects of biogas and raw slurries on grass growth and soil microbial indices. J. Plant Nutr. Soil Sci. 2016, 179, 215-222. [CrossRef]

48. Andruschkewitsch, M.; Wachendorf, C.; Wachendorf, M. Effects of digestates from different biogas production systems on above and belowground grass growth and the nitrogen status of the plant-soil-system. Grassl. Sci. 2013, 59, 183-195. [CrossRef]

49. Hupfauf, S.; Bachmann, S.; Fernández-Delgado Juárez, M.; Insam, H.; Eichler-Löbermann, B. Biogas digestates affect crop P uptake and soil microbial community composition. Sci. Total Environ. 2016, 542, 1144-1154. [CrossRef]

50. Cavalli, D.; Cabassi, G.; Borrelli, L.; Geromel, G.; Bechini, L.; Degano, L.; Marino Gallina, P. Nitrogen fertilizer replacement value of undigested liquid cattle manure and digestates. Eur. J. Agron. 2016, 73, 34-41. [CrossRef]

51. Balesdent, J.; Chenu, C.; Balabane, M. Relationship of soil organic matter dynamics to physical protection and tillage. Soil Till. Res. 2000, 53, 215-230. [CrossRef]

52. Freibauer, A.; Rounsevell, M.D.A.; Smith, P.; Verhagen, J. Carbon sequestration in the agricultural soils of Europe. Geoderma 2004, 122, 1-23. [CrossRef] 
53. Jensen, L.S.; Mueller, T.; Bruun, S.; Hansen, S. Application of the DAISY model for short- and long-term simulation of soil carbon and nitrogen dynamics. In Modeling Carbon and Nitrogen Dynamics for Soil Management; Shaffer, M.J., Ma, L., Hansen, S., Eds.; Lewis Publishers: Boca Raton, FL, USA, 2001; pp. 483-509, ISBN 1566705290.

54. Paustian, K.; Parton, W.J.; Persson, J. Modeling soil organic matter in organic-amended and nitrogen-fertilized long-term plots. Soil Sci. Soc. Am. J. 1992, 56, 476-488. [CrossRef]

55. Morais, T.G.; Teixeira, R.F.M.; Domingos, T. Detailed global modelling of soil organic carbon in cropland, grassland and forest soils. PLoS ONE 2019, 14, e0222604. [CrossRef] [PubMed]

56. Hu, T.; Sørensen, P.; Wahlström, E.M.; Chirinda, N.; Sharif, B.; Li, X.; Olesen, J.E. Root biomass in cereals, catch crops and weeds can be reliably estimated without considering aboveground biomass. Agr. Ecosyst. Environ. 2018, 251, 141-148. [CrossRef]

57. Acharya, B.S.; Rasmussen, J.; Eriksen, J. Grassland carbon sequestration and emissions following cultivation in a mixed crop rotation. Agr. Ecosyst. Environ. 2012, 153, 33-39. [CrossRef]

58. Melzer, M. Influence of Zea mays in Rotations on Isotopic Composition of Soil Organic Matter. Master's Thesis, Technische Universität München, Freising, Germany, 2019. 